\title{
FORCE MEASUREMENTS ON TEETH USING FIXED ORTHODONTIC SYSTEMS
}

\author{
Rebeka T. Rudolf ${ }^{1,2}$, Janko J. Ferčec ${ }^{1}$ \\ ${ }^{1}$ University of Maribor, Faculty of Mechanical Engineering, \\ Slovenia \\ ²Zlatarna Celje d.d., Slovenia
}

FIELD: Materials

DOI: 10.5937/vojtehg61-2960

ARTICLE TYPE: Review Paper

\begin{abstract}
:
The fixed orthodontic appliance consists of brackets that are bonded to the teeth. When the wire is engaged in the slot of the brackets, it generates forces for orthodontic tooth movement. The change in periodontal blood supply provides a biological response which leads to remodelling of the alveolar bone and the orthodontic tooth movement. Many variables influencing orthodontic treatment cannot be controlled fully, such as growth and tissue response to appliances. However, the force placed on the tooth should be a controllable variable, and a careful study of the physics underlying clinical applications can help in reducing undesirable side effects. The properties of orthodontic wires such as: strength, stiffness, elasticity and spring-back define their clinical usefulness. The ideal orthodontic wire should exhibit the following properties: large spring-back, low stiffness, good formability, high stored energy, biocompatibility and environmental stability, low surface friction, and the capability of being welded or soldered to auxiliaries. The ideal arch wire has not been introduced yet. Once the wire is activated or bent, it is the unloading or deactivating forces that produce the orthodontic tooth movement. For these reasons, it is necessary to know the force level caused by each individual wire used in orthodontic treatment. Finally, the purpose of this paper is a presentation of force measurements which are generated by different super-elasticity NiTi wires.
\end{abstract}

Key words: Force Measurements, orthodontic system, teeth, NiTi alloys.

\footnotetext{
${ }^{1}$ ACKNOWLEDGMENT: This article has been supported by the EUREKA Programme OrtoNiTi within the framework of the Ministry of Higher Education, Science and Technology of the Republic of Slovenia and Serbia, and also by the Programme for Young Researcher within the framework of the Slovenian Research Agency. The authors thank Zlatarna Celje d.d., Slovenia and Serbia, for working on the development of the new Ni-Ti alloy.
} 


\section{Introduction}

\section{Dental braces}

Fixed dental braces (Fig. 1) are designed to correct the false bran- ched teeth. They are composed of brackets attached to the teeth and the wire is usually made of NiTi shape memory alloy. The wire has a feature which links it to the teeth so that it always acts with a force. Optimal forces and torques move the teeth depending on the tooth type and the tooth direction and they are usually between 0.1-2 N and 1-50 Nmm. Insufficient forces and torques are ineffective and may extend the treatment duration. Conversely, excessive forces and torques can lead to severe pain, or periodontal damage and large root resorption (Profitt, 2007). For these reasons, it is necessary to know which forces are caused by individual wires.

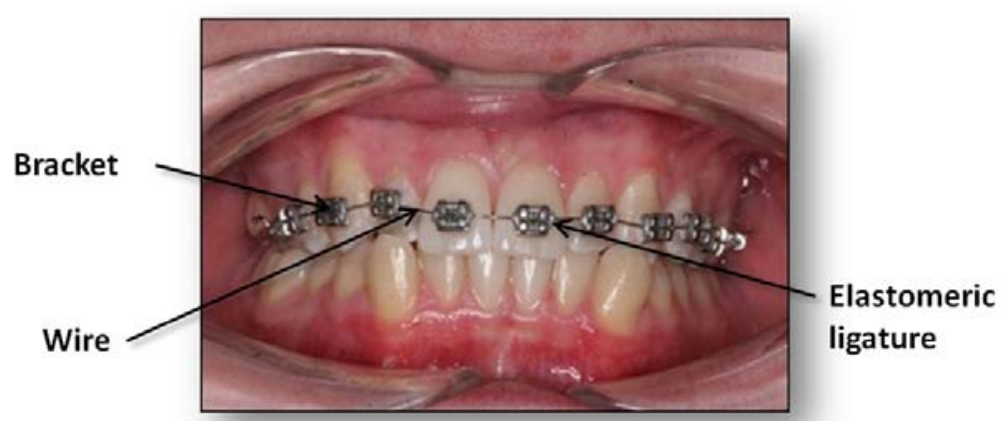

Figure 1 - Dental brace

Slika 1 - Zubna proteza

The force measurement of teeth began with the introduction of dental braces. In the beginning, measured procedures were more simple and imprecise. In recent years, the numbers of experimental devices that measure the forces and torques in three dimensions have grown. In the last five years, research has been conducted in this area that was focused on accurate measurement of the forces on the teeth as a result of the action of orthodontic wires. For these purposes, some "real" experiments have also been made to determine these forces.

\section{Orthodontic wire}

Orthodontic wires are usually made of the NiTi. These materials belong to a group of shape memory materials which are among the group known as functional materials. The first observation of the sha- 
pe memory behaviour of materials goes back to 1932, when Swedish researcher Arne Ölander first noticed this phenomenon on a sample of gold and cadmium (Au-Cd). In 1962, William J. Buehler and his colleagues in the "Naval Ordnance Laboratory" observed the shape memory effect in the alloy of nickel and titanium. This alloy was named NiTiNOL (Nickel-Titanium Naval Ordnance Laboratory) (Lagoudas, 2008).

The use of NiTiNOL wire in orthodontics was introduced by Andreasen in 1971 and is now used increasingly because of its unique elastic properties (Their, et al, 2004, pp. 229-233). The main advantage of $\mathrm{NiTi}$ orthodontic wires compared to conventional (e.g. stainless steel) is their ability to deliver constant stress to push the teeth into the proper position. This property makes this product much more efficient, thus reducing the length of orthodontic treatment for patients. The level of stress in the wire can be controlled through their chemical composition and its thermo-mechanical history. It can also control the geometrical dimensions, as is the case with conventional wires (Coluzzi et al, 1996, pp. 197-205).

\section{Properties of NiTi orthodontic wires}

The reasons why the shape memory alloy NiTi was implemented in medicine or orthodontic treatment are the following: they have an excellent memory properties, excellent mechanical properties, good corrosion resistance and excellent biocompatibility. The most important characteristics for orthodontic application of NiTi alloys are super-elasticity and biocompatibility. These two properties are described below (Profitt, 2007).

\section{Superelasticity}

Orthodontic wires use a special property of the NiTi memory alloy and this is super-elasticity. Super-elasticity is referred to as a reversible martensitic transformation, which is caused due the change in stress or stress state. A sufficiently large load causes the transformation of austenite into martensite (Fig. 2). Unloading returns the transformation of the austenite and the original shape (Lagoudas, 2008). 


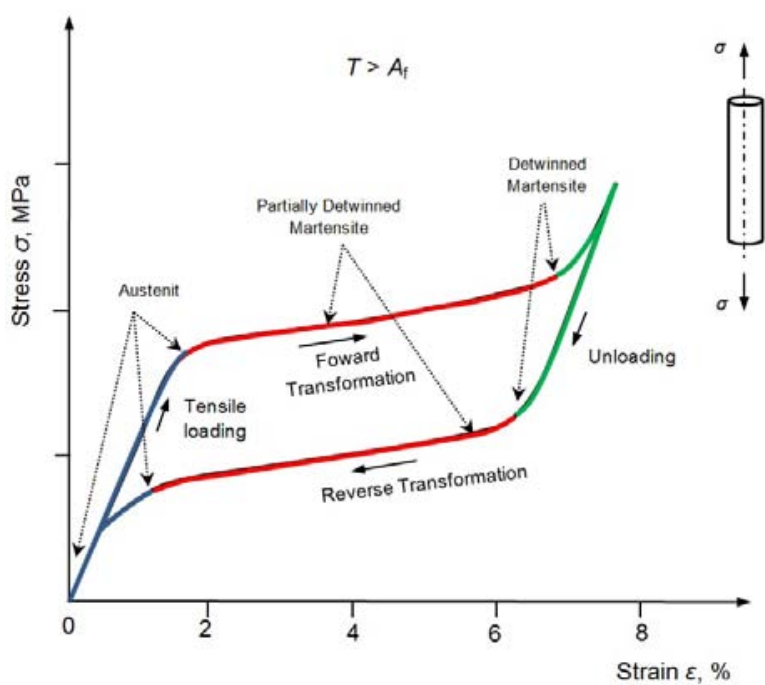

Figure 2 - Diagram of the stress-strain curve for the superelasticity shape memory alloy $\mathrm{NiTi}$ in the tension loading

Slika 2 - Dijagram krive deformacije superelastične memorijske legure NiTi pri opterećenju istezanjem

\section{Biocompatibility}

The generally accepted definition of biocompatibility is very complicated. Williams (1988) described biocompatibility as "the ability of a material to perform with appropriate host response in a specific application". This definition covers the fact that there are many possible interactions between biomaterial and the host, and it does not focus solely on toxicity or injurious effects to the host system. A more concrete definition was proposed in 1998 by Wintermantel, who defined biocompatibility as the structural and surface compatibility between a technical and a biological system, where the structural part is governed by the mechanical properties, and the surface compatibility by the biomaterial superficial physical, chemical, biological and morphological properties. Today, it is necessary to evaluate biocompatibility in accordance with the relevant Standard. Considering the multitude of new advanced materials and devices, a general Standard has been adopted. Using these guidelines, the Standard allows easier comparison of results, while allowing flexibility for individual purposes/needs (Es-Souni, et al, 2004, pp. 557-567). NiTi alloys have a high degree of biocompatibility. In the oxidation reaction of titanium, a surface layer of harmless $\mathrm{TiO}_{2}$ is formed surrounding the sample. This layer has the high corrosion resistance of titanium alloy and is generally harmless to the human body. Because of the 
biocompatibility and good mechanical properties of NiTi alloys, there are many opportunities to develop and improve products for application in biomedicine (Auricchio, Massarotti).

\section{General principles of force activity}

Fig. 3 shows the procedure of treatment, respectively tooth movement in the proper position by means of force; Fig. 3a shows a settlement of teeth in the arch, while Fig. $\mathbf{3 b}$ shows the settlement of teeth in the plane of the teeth.
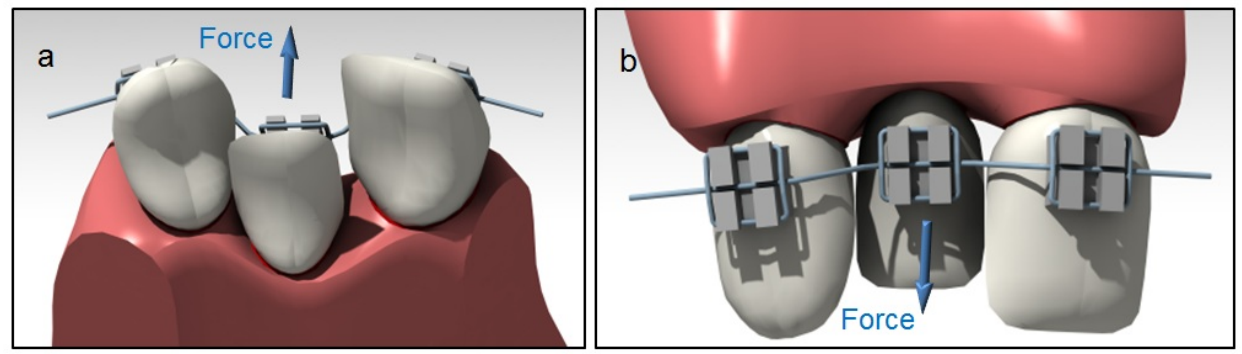

Figure 3 - Presentation of needed force by treatment Slika 3 - Prikaz zahtevane sile pri lečenju

On this basis, it will be necessary to determine the most optimal wire that does not cause excessive and not too small a stress to the periodontal ligament (PDL). The level of stress in the wire will be controlled through its chemical composition and thermo-mechanical history, as well as geometric dimensions (Lagoudas, 2008). The accuracy of the results will be verified by experiments on a model, where we will measure the actual forces and torques. The purpose of our study is to measure the forces generated by different superelasticity $\mathrm{NiTi}$ wires. Fig. 4 shows the direction of the forces on the tooth (Ferčec, et al, 2012).

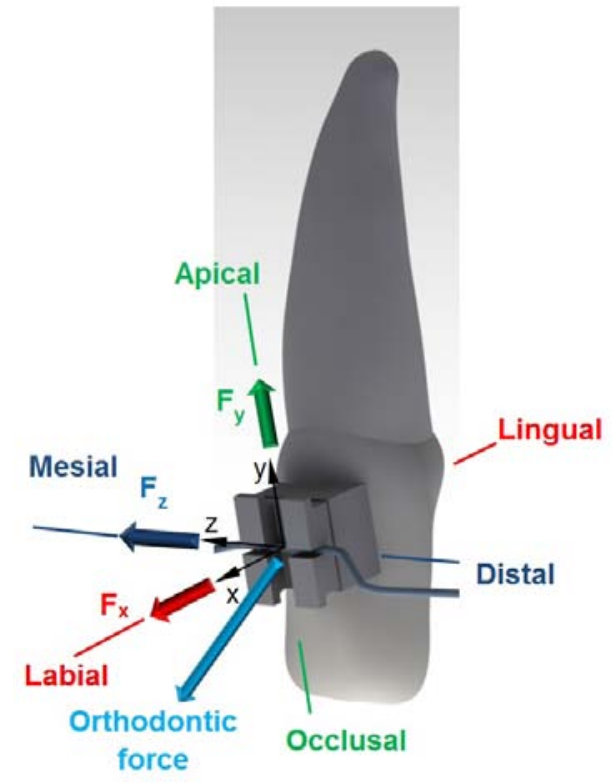

Figure 4 - Direction of the forces on the tooth Slika 4 - Pravci delovanja sila na zub 


\section{State of the art}

In the last five years, research has been conducted in this area, focusing on accurate measurement of the forces on the teeth as a result of the action of orthodontic wires. For these purposes, some "real" experiments have also been made to determine these forces.

Since 1970, numerical methods which have been developed with a computer programme have been used (de Weck, Yong). Research works have been conducted by the Finite Element Method (FEM), related to the determination of stress in the periodontal ligament (PDL) and displacement of teeth under orthodontic force (Norman, et al, 2010. pp. 98-108), (Chang, et al, 2004, pp. 339-45), (Kojimaa, Fukuib, 2010), (Qian, Fan, Liu \& Zhang, 2008, pp. 48-52), (Field, et al, 2009, pp. 174-181).

In the literature has so far worked by using force measurement directly on the teeth by the Finite Element Method under orthodontic force. The Table below shows the articles that have been published on this subject in various scientific journals.

The force measurement of teeth began with the introduction of dental braces. In the beginning, measured procedures were more simple and imprecise. In recent years, the numbers of experimental devices that measure the forces and torques in three dimensions have grown. Various experimental procedures were published in different journals (Fuck, et al, 2007, pp. 363-376), (Lapatki, Paul, 2009, 377-396), (Hisham, et al, 2009, pp. 518-528), (Milczewski, et al, 2007), (Sifakakis, et al, 2009, pp. 30511), (Fuck, Drescher, 2010, pp. 6-18), (Lapatki, et al, 2007, pp. 73-78).

\section{Examples of forces measurement with the experiment}

\section{Example 1:}

Lars-Michael Fuck, Dirk Wiechmann and Dieter Drescher were involved in measuring the forces and torque applied to the teeth. In the study they researched the forces and torques created by using a new lingual bracket (Fig. 5) through the phase of the orthodontic treatment. This dental brace was compared with a labial straight-wire appliance. The samples within the mouth were scanned in 10 patients and, with the method of "rapid prototyping-a", they made models of their teeth. Then they measured the initial forces and moments with a robotic measuring device (see Fig. 6). The measurements were performed at a temperature of $37^{\circ} \mathrm{C}$ (Fuck, et al, 2007, pp. 363-376). 


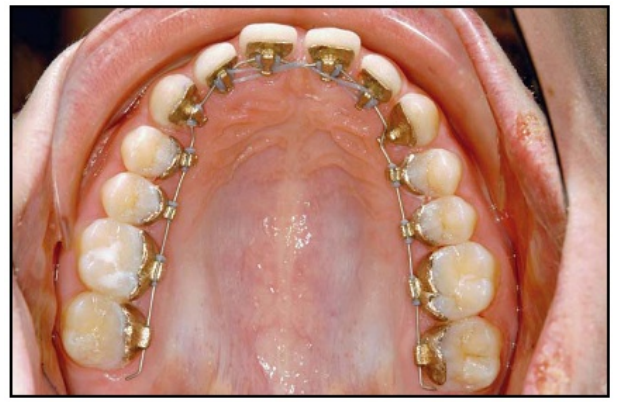

Figure 5 - Intra-oral view of the Incognito lingual brackets Slika 5 - Prikaz usne duplje s nevidljivom fiksnom protezom
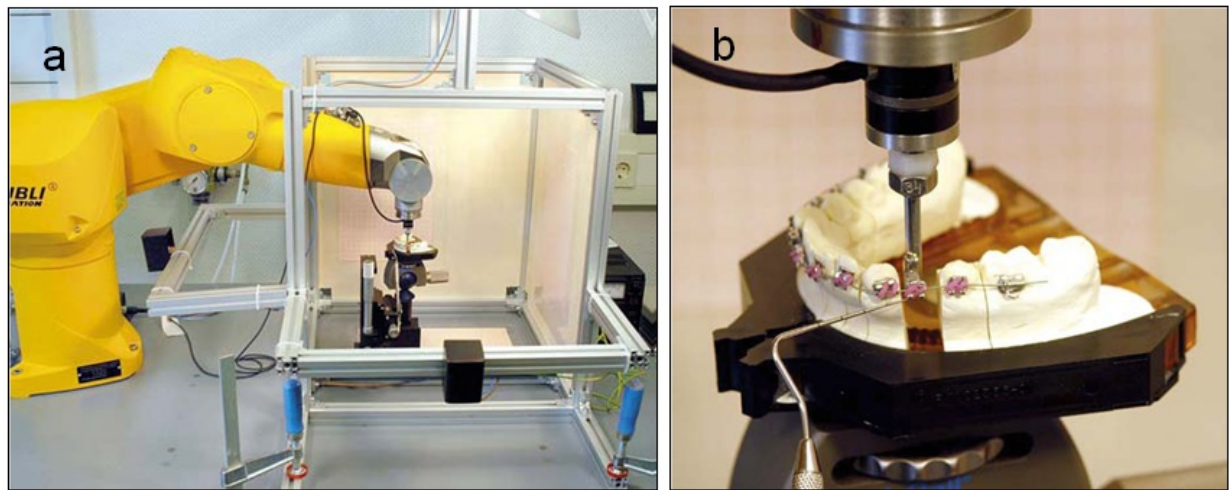

Figure 6 - (a) Robotic-Measurement-System (b) positioned and ligated measurement bracket (Sifakakis, et al, 2009, pp. 305-11)

Slika 6 - (a) Robotički merni sistem (b) postavljena i povezana merna proteza

(Sifakakis, et al, 2009, str. 305-11)

Forces and moments were analyzed in all models included in all teeth measured. The forces and torques were then presented as the length of the corresponding vector. The statistical analysis of the average force of all ten casts revealed no significant differences between lingual and labial brackets in connection with the forces, while the moments were different.

\section{Example 2:}

Bernd G. Lapatki and Oliver Paul researched by using force measurements and moments through the sensor (see Figs. 7, 8). The feasibility of this accession was demonstrated using the Finite Element Method (FEM). The sensor was of a very small size so that it could be integrated into the bracket (Fig. 9) (Lapatki, Paul, 2009, 377-396). 


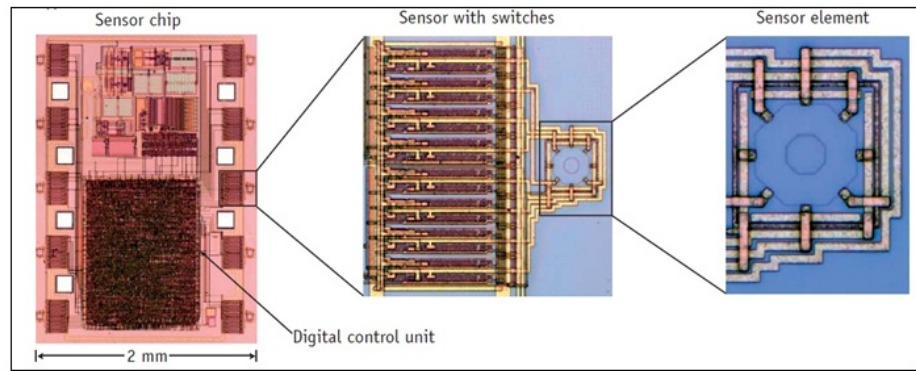

Figure 7 - Micrograph of the sensor chip (measuring $2 \times 2.5 \mathrm{~mm}^{2}$ ) Slika 7 - Mikrofotografija čipa senzora (dimenzija 2x2,5 $\mathrm{mm}^{2}$ )

The micrograph in Fig. 7 is applicable to manufacture true-scale smart brackets. The actual sensor element (rightwards) measures only the area of $50 \times 50 \mu \mathrm{m}^{2}$. The eight contacts permit current flow in different directions („spinning-current method“), (Hisham, et al, 2009, pp. 518-528).
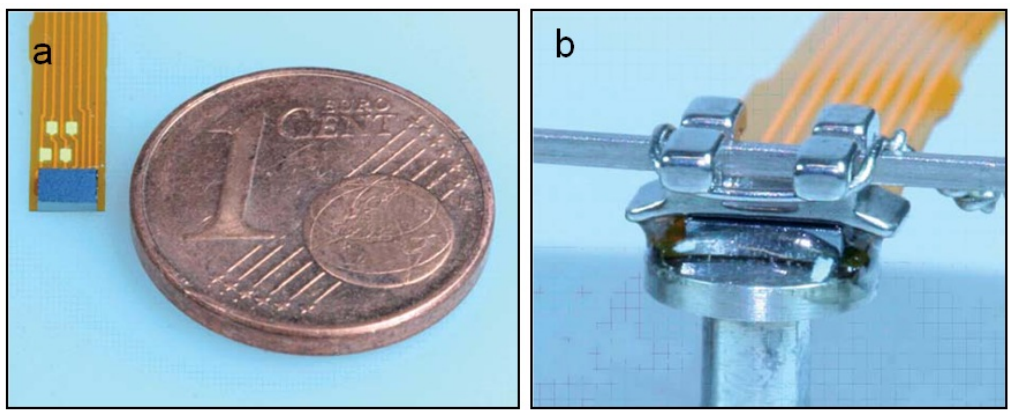

Figure 8 - Miniaturized sensor system was connected: (a) electrically using flip-chip bonding, (b) true-scale smart bracket with the adhesively-attached slot, the inserted wire and the mounting pin (Hisham, et al, 2009, pp. 518-528).

Slika 8 - Minijaturni senzorski system je povezan (a) električnim putem pomoću flip-chip veze (b) pametni breket stvarne veličine sa zalepljenim slotom, umetnutom žicom i nosećom iglom (Hisham, et al, 2009, pp. 518-528).

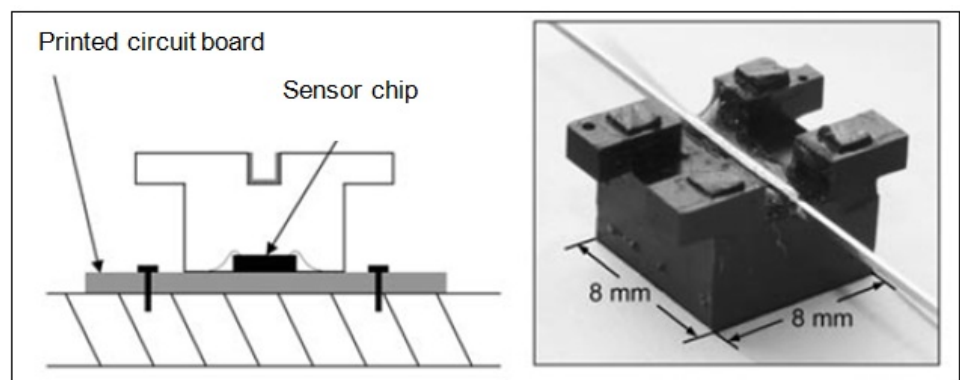

Figure 9 - Installation of the sensor chip in the bracket (Scheid, Weiss, 2012) Slika 9 - Instaliranje senzorskog čipa u breketu (Scheid, Weiss, 2012) 


\section{Example 3:}

The latest, more high-profile research, discussed in articles, has been undertaken by Hisman M. Badawi and his co-workers (Hisham, et al, 2009, pp. 518-528). In their study, they measured forces and torques using nanosensors. The experiment is shown in Figs. 10 and 11 (Hisham, et al, 2009, pp. 518-528).
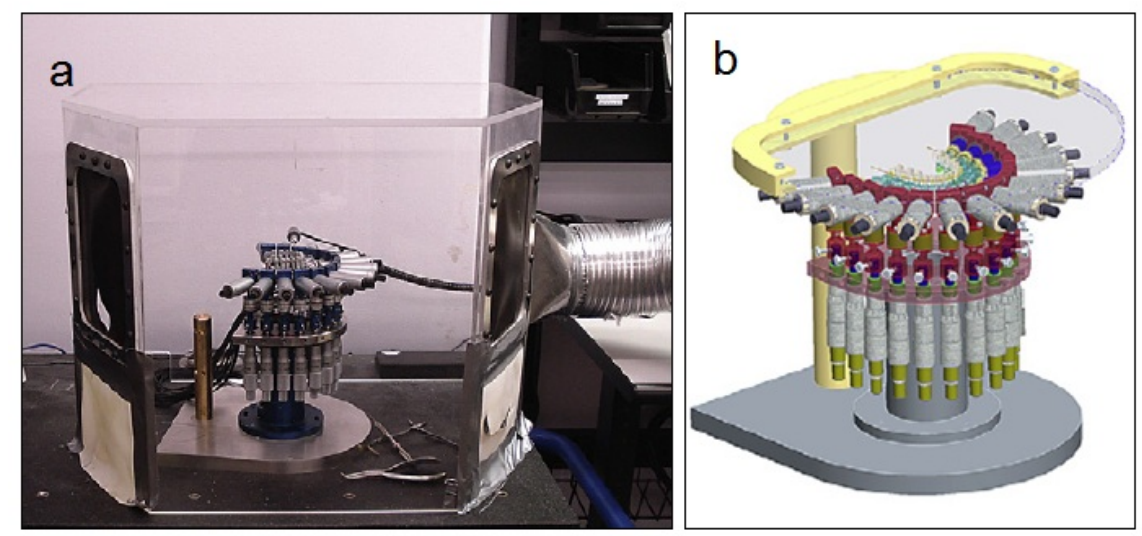

Figure 10 - (a) OSIM device in a temperature chamber; (b) 3D model of the device Slika 10 - (a) OSIM uređaj u temperaturnoj komori, (b) trodimenzionalni model uređaja

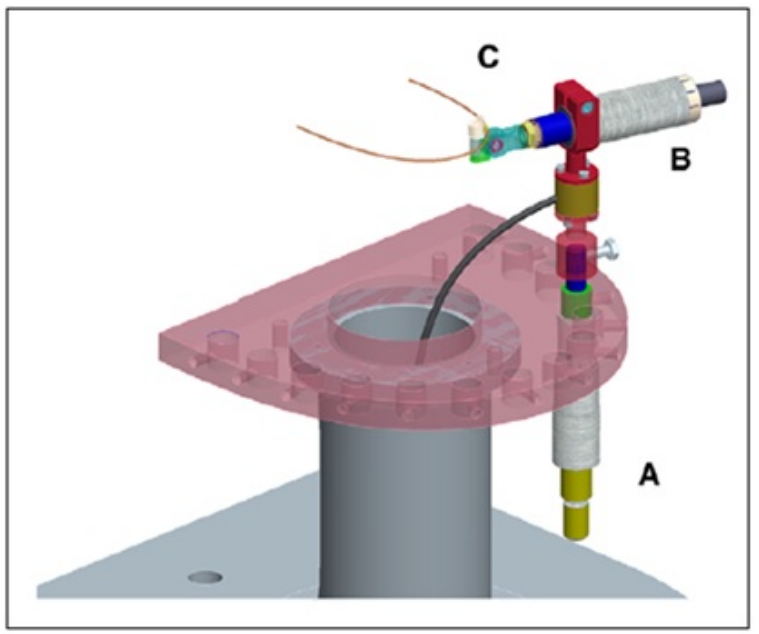

Figure 11 - Load cell: A- vertical micrometer; B-horizontal micrometer; C-tooth adapter Slika 11 - Merna ćelija A -vertikalni mikrometar, B-horizontalni mikrometar,

C- adapter zuba 


\section{Numerical method solution for the determination of the orthodontic forces}

Numerical methods have been used to define the force caused on the teeth by different types of super-elasticity NiTi wires attached to the front surface of teeth at various angles. In doing so, we hope to establish what stress the wire causes on the periodontal ligament. With respect to permissible stress in the ligament, we will define the characteristics of the super-elastic wire. On the basis of the results and properties, we will give guidance and a directive for selecting the optimal wire.

In order to confirm the numerical model successfully, we will experiment "in vitro" with the most realistic conditions, using wires and brackets. In this way, we will try to verify the obtained results with a numerical simulation. We will do simplified $3 D$ models of the orthodontic wire, the bracket, teeth and tissues with the CATIA software. The software tool for the numerical simulation of ABAQUS will define all load properties and also a stress calculation, from which we can then calculate the force. The obtained results have been analyzed.

The information on the forces and torque generated by the action of the teeth wire in dental braces is important for the dentist - orthodontics and especially for patients who use this device. In this way, orthodontists obtain information about the wires placed in the mouth to assure sufficient force on the tooth, to align the teeth more rationally, quickly and painlessly for the patient who wears the dental braces. Nevertheless, the studies which determine what should be a force on the teeth so that there is no pain for patients and that treatment does not last too long, are already known.

Based on clinical studies, we assume that we can identify the most optimal force caused by wire. From the knowledge of these forces, a wire that will have specific super-elastic properties can be chosen. This is influenced by an appropriate chemical composition (the content of $\mathrm{Ni}$ and Ti) and the geometry of wires (cross section). The presented problems are difficult, because people have different properties of the tissue in the mouth (they change even locally) or the state of the periodontal ligament, which is important in moving the teeth to the proper position.

The orthodontic 3D model for this study was built using CATIA V5 software. A 3D model of a crowded central incisor, lateral incisor and canine in the upper dental arch simulated real malocclusion. A fixed orthodontic appliance was used to simulate the orthodontic treatment in a case with moderate crowding. Metal brackets were bonded to the teeth and wire inserted into the slots. Data for tooth dimensions were taken from the literature (Scheid, Weiss, 2012). The teeth crowns in the model had the following heights and mesio-distal widths, respectively: $11.2 \mathrm{~mm}$ and 
$8.6 \mathrm{~mm}$ for the central incisor, $9.8 \mathrm{~mm}$ and $6.6 \mathrm{~mm}$ for the lateral incisor and $10.6 \mathrm{~mm}$ and $7.6 \mathrm{~mm}$ for the canine. The root lengths were: $13 \mathrm{~mm}$ for the central incisor, $13.4 \mathrm{~mm}$ for the lateral incisor and $16.5 \mathrm{~mm}$ for the canine. The position of the teeth in the model resembled moderate crowding in the upper dental arch. The lateral incisor was moved $4 \mathrm{~mm}$ lingual and $3 \mathrm{~mm}$ gingival from its normal position in the dental arch in order to present moderate crowding. A 3D model of the upper frontal teeth was obtained, with the periodontal ligament modelled for the length of the whole root (0.25 mm in width) (Fig. 12). A supportive bone was modelled in a $2 \mathrm{~mm}$ thick layer, with the underlying cortical bone. The orthodontic $\mathrm{NiTi}$ wire was inserted into the bracket slot of each tooth in the model. For the wire model, a diameter of $0.012 "(0.305 \mathrm{~mm})$ was taken into consideration.

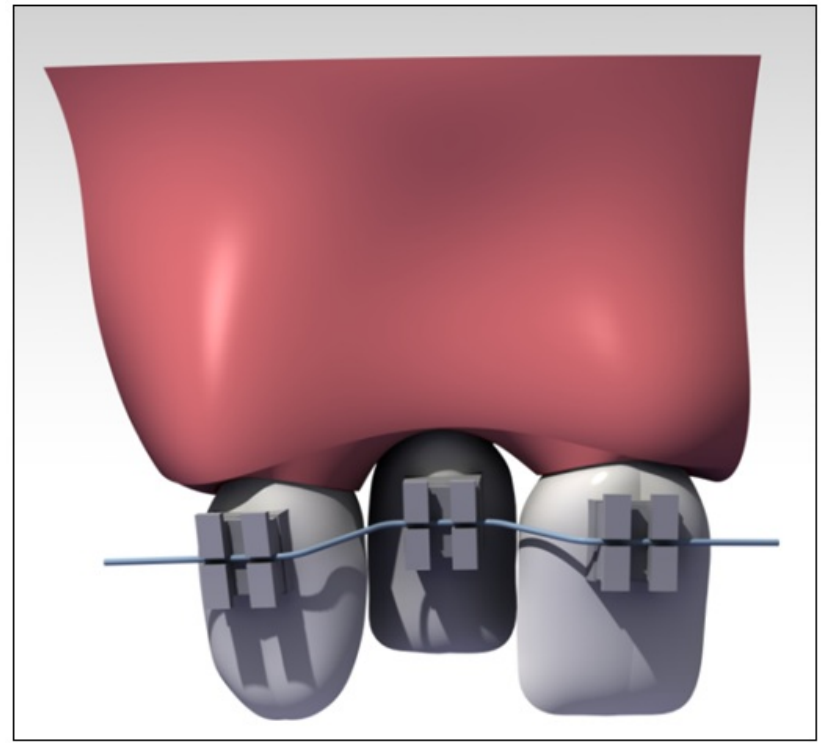

Figure 12 - CAD model of tooth position Slika 12 - CAD model položaja zuba

The 3D model was based on the thesis that all materials are isotropic materials, which means that there are two independent material constants. In order to simplify the model, materials were considered to be homogeneous, meaning that linear and elastic material behaviour included two constants: Young's modulus and a Poisson ratio. The values of Young's modulus and Poisson ratio for the alveolar bone, periodontal ligament, tooth and bracket were taken from literature (Table I) (Todorović, et al, 2010, pp. 41-47). 
Table 1 - Young's modulus and Poisson number Tabela 1 - Jungov modul i Poasonov broj

\begin{tabular}{|c|c|c|}
\hline $\begin{array}{c}\text { Linear-elastic material } \\
\text { parameters used for: }\end{array}$ & $\begin{array}{c}\text { Young's Modulus of } \\
\text { Elasticity, } \\
\text { E [MPa] }\end{array}$ & $\begin{array}{c}\text { Poisson's } \\
\text { ratio }\end{array}$ \\
\hline Alveolar bone & $13800^{18}$ & $0.30^{18}$ \\
\hline Teeth & $20000^{18}$ & $0.30^{18}$ \\
\hline Periodontal ligament & $1^{23}$ & $0.45^{23}$ \\
\hline Bracket (stainless steel) & 180000 & 0.3 \\
\hline
\end{tabular}

In the numerical analysis that was performed, three different NiTi orthodontic wires with various modulus of elasticity (Table II) were used. The purpose of the analysis was to determine the initial force when the wire was inserted into the slot of the brackets and ligated. Although the behaviour of NiTi wires in terms of superelasticity is complex, we simplified the material properties, and the modulus of austenite for numerical analysis was taken (Auricchio, Taylor, 1997, pp. 175-194), (Šestak, Černy, Pokluda, 2009). The NiTi orthodontic wires at a given stress have martensitic structure which transforms during treatment back to austenite. The data for the austenite modulus for various wires are presented in Table II (Proffit, 2007, pp. 359-394). In all three wires the Poisson number was 0.3 (Proffit, 2007, pp. 359-394).

Table 2 - Material parameter of wires for the numerical model Tabela 2 - Parametar materijala žica za numerički model

\begin{tabular}{|c|c|}
\hline Wire & $\begin{array}{c}\text { Young's Modulus of } \\
\text { martensite, } E[\mathrm{MPa}]\end{array}$ \\
\hline 1. & 50000 \\
\hline 2. & 54000 \\
\hline 3. & 58000 \\
\hline
\end{tabular}

The brackets and wire were meshed by hexagonal finite elements (Fig. 13). In a real orthodontic treatment, especially in the levelling stage, it is desirable for the wire to slide through the slot of the bracket as freely as possible having the least friction (Proffit, 2007, pp. 359-394). In order to choose an orthodontic wire wisely, it is important to know the friction properties between the wire and the bracket. The information about these properties in the literature has not been consistent. It is very difficult to determine accurately the friction characteristics between the wire and the bracket, because the contact conditions between them vary widely. For the friction coefficient between the wire (NiTi) and the bracket (stainless steel) a value of 0.3 (Noda, et al, 1993, pp. 
154-160) was taken from the literature. The boundary conditions for load were taken from the surface stress in the wire.

By using the ABAQUS software for numerical simulation, a model with three different orthodontic wires was presented. The values of the stress on the bracket, PDL and the lateral incisor itself produced by different types of wires are shown in Figs. 14a, 14b and 14c. It can be seen that by increasing the elastic modulus of the wire, the stresses on the bracket, PDL and tooth became more intense.

Figure 13 - The finite-element mesh of the model Slika 13 - Mreža konačnih elemenata modela

Fig. 15 shows Von Mises equivalent stresses on the PDL of the lateral incisor. We could see that on the PDL the compressive stresses in the tensile stresses zone are similar to the formatted stresses on the lateral incisor. The maximal equivalent stress after Von Mises on the PDL of the lateral incisor is formatted on the circumference of the PDL by the contact with the tooth crown. Bigger stresses on the mesial side than on the distal side are probably consequences of the smaller distance between the bracket on the lateral incisor and the bracket on the canine. The second reason could be also a stiff contact between the bracket and the wire.

Figure 14 - Von Mises equivalent stresses on the tooth lateral incisor:

(a) $\mathrm{E}=50000 \mathrm{MPa}$; (b) $\mathrm{E}=54000 \mathrm{MPa}$;

(c) $\mathrm{E}=58000 \mathrm{MPa}$

Slika 14 - Ekvivalentni fon Mizesov napon na bočni sekutić

(a) $\mathrm{E}=50000 \mathrm{MPa}$; (b) $\mathrm{E}=54000 \mathrm{MPa}$;

(c) $\mathrm{E}=58000 \mathrm{MPa}$
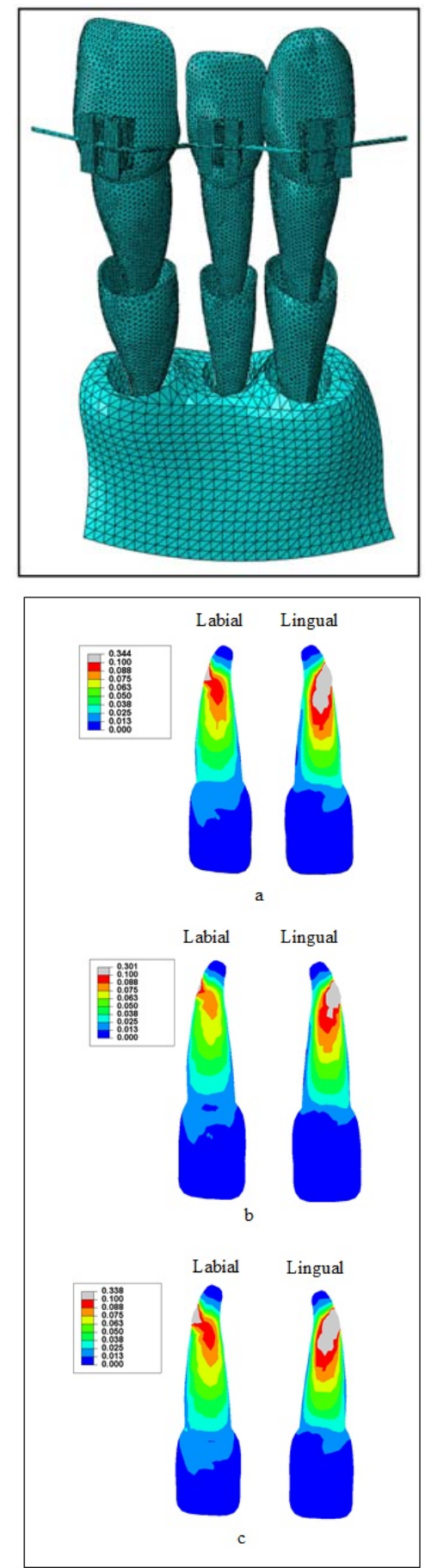


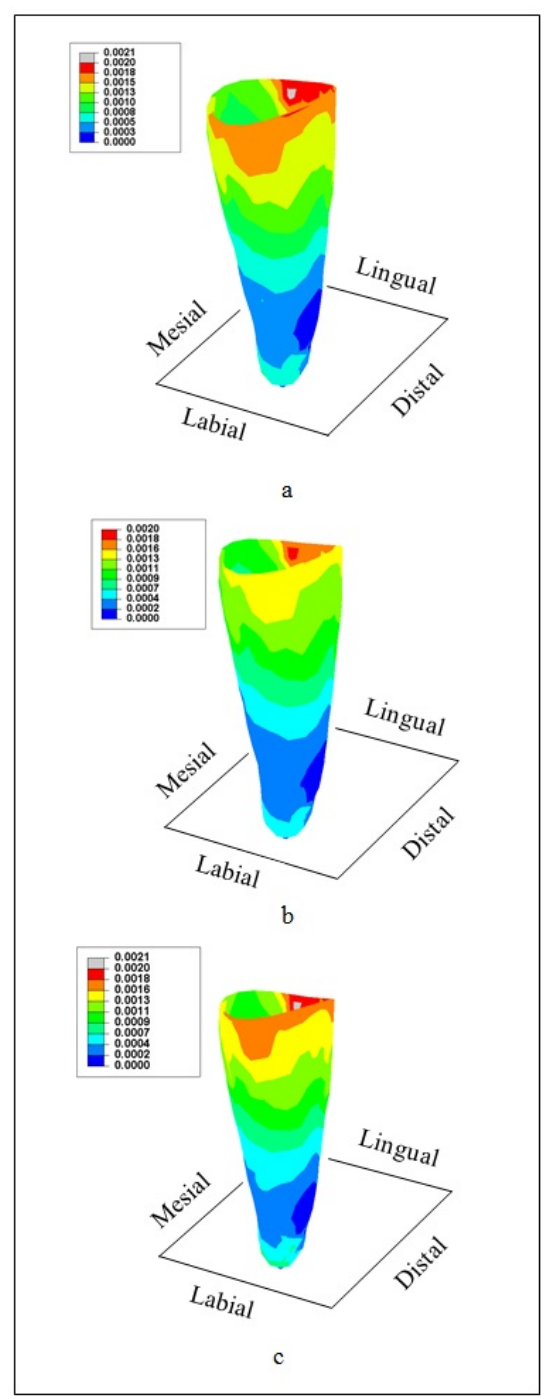

Figure 15 - Von Mises equivalent stresses on the periodontal ligament: (a) $\mathrm{E}=50000 \mathrm{MPa}$; (b) $\mathrm{E}=54000 \mathrm{MPa}$; (c) $\mathrm{E}=58000 \mathrm{MPa}$

Slika 15 - Ekvivalentni fon Mizesov napon na parodontalnom ligamentu (a) $\mathrm{E}=50000 \mathrm{MPa}$; (b) $\mathrm{E}=54000 \mathrm{MPa}$; (c) $\mathrm{E}=58000 \mathrm{MPa}$

Table III shows the average Von Mises equivalent stresses for the separate internal force and the calculated resultant force. The force level was obtained with this simulation. The average Von Mises equivalent stresses were calculated using the values on the cut plane of the bracket- 
Table 3 - The average Von Mises equivalent stresses, internal forces on the cut plane of the bracket and the calculated resultant forces

Tabela 3 - Prosečni ekvivalentni fon Mizesov napon, unutrašnje sile na ravan breketa i izračunate rezultujuće sile

\begin{tabular}{|c|c|c|c|c|c|c|c|}
\hline \multirow{2}{*}{$\begin{array}{l}\mathbf{i} \\
\mathbf{r} \\
\mathbf{e}\end{array}$} & \multicolumn{3}{|c|}{ Average stresses [MPa] } & \multicolumn{3}{c|}{$\begin{array}{c}\text { Components of internal } \\
\text { forces [N] }\end{array}$} & $\begin{array}{c}\text { Ortho- } \\
\text { dontic } \\
\text { force [N] }\end{array}$ \\
\cline { 2 - 8 } & $\sigma_{\mathrm{xx}}$ & $T_{\mathrm{xy}}$ & $T_{\mathrm{xz}}$ & $F_{\mathrm{x}}$ & $F_{\mathrm{y}}$ & $F_{\mathrm{z}}$ & $F$ \\
\hline 1 & 0.0341 & -0.012 & -0.0015 & 0.35 & -0.12 & -0.016 & 0.37 \\
\hline 2 & 0.0346 & -0.0121 & -0.00152 & 0.354 & -0.124 & -0.0156 & 0.375 \\
\hline 3 & 0.035 & -0.0124 & -0.00161 & 0.358 & -0.127 & -0.017 & 0.38 \\
\hline
\end{tabular}

The Finite Element Method (FEM) is a powerful tool for the analysis of complex structures, but the outcome is dependent on the formulation of the problem (Toms, Eberhardt, 2003, pp. 657-65). The acting forces in the beginning stage of orthodontic treatment in the case with moderate crowding were presented using the FEM. This was an attempt to quantify and evaluate the effects of orthodontic loads applied to the bracket and teeth in order to achieve initial tooth movement. With the intention of simplifying the procedure, the moment of force was not taken into account. The emphasis was put on the level of force produced by the NiTi wire. It was determined that, by the smallest elastic modulus of 50,000 $\mathrm{MPa}$, the calculated force on the lateral incisor was approximately $0.37 \mathrm{~N}$. A bigger force was produced by the wires with a higher value of elastic modulus. The force level was smaller than it is supposed to be optimal for orthodontic tooth movement (0.09-0.98 N).

\section{Conclusions}

In the past, numerous studies have been carried out to determine the actual level of force applied to the teeth, in which the initial force caused by orthodontic wires was measured by means of load cells on specially constructed models.

In the present study, the level of the orthodontic forces caused by the the initial NiTi wire was determined using the Finite Element Method (FEM). For the simulation we used commercially available software for numerical simulation by FEM - Abaqus. The numerical model with boundary conditions similar to those in the mouth was constructed. Much emphasis was placed on the choice of material parameters and biological segment in the numerical model. 
Material parameters such as an elastic module and Poisson's ratio for the bone and teeth were available. The determination of the material parameters of the periodontal ligament was difficult due to the small space of the ligament that surrounds the tooth. In the present 3D computer model simulating the force system in a simple orthodontic case, we presented the stresses on the periodontal ligament. The results of simulation showed that complex stresses were created due to various components of the forces applied to the tooth. The calculation of individual and resultant forces was done at the same time taking into consideration two components of the force applied to the brackets on the tooth: normal and tangential. The results indicated that the calculated force is in the range of predicted optimal force for orthodontic tooth movement.

In this paper, a numerical simulation of a complex biological system with applied orthodontic forces was shown. Although the numerical simulation required substantial simplification of a real life situation, the results are clinically relevant. The future of the numerical model lies in the ability to introduce more relevant parameters into the successful simulation of more complex orthodontic problems.

\section{References}

Auricchio, F., \& Massarotti, V. One Way and Two Way-Shape Memory Effect: Thermo-Mechanical Characterization of Ni-Ti wires. Retrieved from http://www. 2.unipv.it/compmech/dissertations/zanaboni.pdf. 175-194

Auricchio, F., \& Taylor, R. 1997. Comput. Meth. Appl. Mech. Eng., 143, pp.

Chang, Y., Shin, S., \& Baek, S. 2004. Three-dimensional finite element analysis in distal en masse movement of the maxillary dentition with the multiloop edgewise archwire. Eur J Orthod, 26(3), pp. 339-45. pmid:15222721. doi:10.1093/ejo/26.3.339

Coluzzi, B., Biscarini, A., di Massoa, L., Mazzolai, F.M., Staffolanib, N., Guerrab, M., Tuissi, A. 1996. Phase transition features of NiTi orthodontic wires subjected to constant bending strains. Journal of Alloys and Compounds, 233(12), pp. 197-205.

de Weck, O., \& Yong, K.I. Finite Element Method. Retrieved from http://web.mit.edu/16. 810/www/16. 810_L4_CAE.pdf.

Es-Souni, M., \& Fischer-Brandies, H. 2004. Assessing the biocompatibility of NiTi shape memory alloys used for medical applications. Analytical and Bioanalytical Chemistry, 381(3), pp. 557-567.

Ferčec, J., Glišić, B., Šćepan, I., Marković, E., Stamenković, D., Anžel, I., Flašker, J., Rudolf, R., 2012, Determination of Stresses and Forces on the Orthodontic System by Using Numerical Simulation of the Finite Elements Method. A. Phys. Polonica A 2012; 122: 659-665.

Field, C., Ichim, I., Swain, M.V., Chan, E., Darendeliler, M.A., Li, W., \& Lig, Q. 2009. Mechanical responses to orthodontic loading: A 3-dimensional finite 
element multi-tooth model. American Journal of Orthodontics and Dentofacial Orthopedics., 135(2), pp. 174-181.

Fuck, L.M., \& Drescher, D. 2010. Force Systems in the Initial Phase of Orthodontic Treatment: A Comparison of Different Levelling Archwires. Journal of Orofacial Orthopaedics, 67(1), pp. 6-18.

Fuck, L.M., Wiechmann, D., \& Drescher, D. 2007. Comparison of the Initial Orthodontic Force Systems Produced by a New Lingual Bracket System and a Straight-Wire Appliance. Journal of Orofacial Orthopaedics, 66(5), pp. 363-376.

Hisham, M., Badawia, R., Toogoodb, W., Jason, P.R., Heod, C.G., \& Paul, W.M. 2009. Three-dimensional orthodontic force measurements. American Journal of Orthodontics and Dentofacial Orthopedics., 136(4), pp. 518-528.

Kojimaa, Y., \& Fukuib, H. 2010. Numeric simulations of en masse space closure with sliding mechanics. American Journal of Orthodontics and Dentofacial Orthopedics., 138(6).

Lagoudas, D.C. 2008. Shape Memory Alloys, Modeling and Engineering Applications. Texas: Springer.

Lapatki, B.G., Bartholomeyczik, J., Ruther, P., Jonas, I.E., \& Paul, O. 2007. Smart Bracket for Multi-dimensional Force and Moment Measurement. Journal of Dental Research, 86, pp. 73-78.

Lapatki, B.G., \& Paul, O. 2009. Smart Brackets for 3D-Force-Moment Measurements in Orthodontic Research and Therapy: Developmental Status and Prospects. Journal of Orofacial Orthopaedics, 68(5), pp. 377-396.

Milczewski, M.S., Martelli, C., Canning, J., Stevenson, M., Simoes, J., \& Kalinowski, H. 2007. Measurement of orthodontic forces using polymer PCF. In: Optical Internet, 32nd Australian Conference on Optical Fibre Technology, COIN-ACOFT Joint International Conference.

Noda, T., Okamoto, Y., \& Hamanaka, H. 1993. . J. Jpn Orthod Soc, 52(2), pp. 154-160.

Norman, D.P., Carlos, N.E., Pacheco, M.C., Thomé, G., \& Pereira, J. 2010. 3D simulation of orthodontic tooth movement. J. Orthod., 1(5), pp. 98-108.

Proffit, W.R. 2007. Contemporary orthodontics. St. Louis: Elsevier, Mosby, pp. 359-394.

Qian, Y., Fan, Y., Liu, Z., \& Zhang, M. 2008. Numerical simulation of tooth movement in a therapy period, pp. 48-52.

Scheid, R.C., \& Weiss, G. 2012. Woelfels Denatal Anatomy.Lippincott Williams \& Wilkins.

Sifakakis, I., Pandis, N., Makou, M., Eliades, T., \& Bourauel, C. 2009. Forces and moments on posterior teeth generated by incisor intrusion biomechanics generated by incisor intrusion biomechanics. Orthod Craniofac Res., 12(4), pp. 305-11.

Šestak, P., Černy, M., \& Pokluda, J. 2009. Influence of compound twinning on Youngs moduli in NiTi martensite. Retrieved from http://www.esomat.org

Their, M., Treppmann, D., Drescher, D., \& Boureaul, C. 2004. Transformation characteristics and related deformation behaviour in orthodontic NiTi wire. Journal of Materials Science: Materials in Medicine, 3, pp. 229-233. 
Todorović, A., Radović, K., Grbović, A., Rudolf, R., Maksimović, I., \& Stamenković, D. 2010. Stress analysis of a unilateral complex partial denture using the finite-element method. Materijali i tehnologije, 44(1), pp. 41-47.

Toms, S.R., \& Eberhardt, A.W. 2003. A nonlinear finite element analysis of the periodontal ligament under orthodontic tooth loading. American Journal of Orthodontics and Dentofacial Orthopedics., 123(6), pp. 657-65. pmid:12806346

\title{
METODE MERENJA SILA NA ZUBIMA KOD FIKSNOG ORTODONTSKOG SISTEMA
}

\author{
OBLAST: materijali \\ VRSTA ČLANKA: pregledni članak
}

Sažetak:

Fiksni ortodontski aparat sastoji se od bravica (breketa) povezanih zubima. Nakon provlačenja kroz otvore na breketima, žica generiše silu koja utiče na ortodontsko pomeranje zuba. Promena u parodontalnom dotoku krvi predstavlja biološki odgovor koji dovodi do preoblikovanja alveolarne kosti i ortodontskog pomeranja zuba. Mnoge promenljive koje utiču na ortodontsko pomeranje zuba, poput rasta i odgovora tkiva na aparat, ne mogu da se kontrolišu u potpunosti. Međutim, sila kojom se deluje na zub treba da bude promenljiva i na nju se može uticati, a pažljivo izvedeno ispitivanje fizičke osnove kliničkih primena može da bude od pomoći pri smanjivanju neželjenih sporednih efekata. Osobine ortodontskih žica, kao što su jačina, krutost, elastičnost $i$ spring-back efekat definišu njihovu kliničku primenljivost. Idealna ortodontska žica treba da poseduje sledeće osobine: izražen spring-back efekat, nisku krutost, dobru obradivost, visok nivo uskladištene energije, biokompatibilnost i stabilnost u okruženju, malo površinsko trenje, kao i sposobnost zavarivanja i lemljenja s pomoćnim delovima. Idealna žica za luk još nije pronađena. Kada se žica aktivira ili savije, ortodontsko pomeranje zuba vrši se pod uticajem rasterećenja ili deaktiviranja sila. Stoga je potrebno znati nivo sile koju proizvodi svaka žica pojedinačno pri ortodontskom lečenju. Cilj ovog rada je da izmeri sile nastale dejstvom različitih superelastičnih NiTi žica.

Ključne reči: merenje sila, ortodonski sistem, zubi, legure bazirane na niklu i titanu

Datum prijema članka/Paper received on: 25. 11. 2012.

Datum dostavljanja ispravki rukopisa/Manuscript corrections submitted on:

20. 03. 2013

Datum konačnog prihvatanja članka za objavljivanje/ Paper accepted

for publishing on: 22. 03. 2013. 